\title{
A Critical Analysis of Tax Avoidance in the South African Income Tax Act 58 of 1962, as Amended
}

\author{
Jean Chrysostome Kanamugire
}

Lecturer, Faculty of Law, North-West University

Email: jean.kanamugire@nwu.ac.za

\section{Doi:10.5901/mjss.2013.v4n6p351}

\begin{abstract}
Everybody can organise his or her business in order to reduce, postpone or avoid tax, as long as he or she operates within the boundaries of the legislation. Tax avoidance is evil, as it deprives the state of the resources that it can use to meet its expenditure and responsibilities. Previously, the Commissioner had to prove that a transaction, operation or scheme had been entered into with the sole or main purpose of avoiding, postponing or reducing the liability to pay tax. The arm's length test and abnormality test needed to be satisfied for the Commissioner to succeed in preventing tax avoidance. Tax avoidance had to be the whole or main purpose of a transaction, operation or scheme. These provisions were very weak and the Commissioner did not succeed in his or her activities. The new Amendment has introduced new remedies for the Commissioner to use to prevent impermissible tax avoidance arrangements. The Amendment protects the Commissioner to the detriment of the taxpayers. There is a provision for impermissible tax avoidance arrangement but the legislature did not provide for permissible tax avoidance arrangements. The new provisions for tax avoidance seem to structure how taxpayers should arrange their businesses. It is recommended that the law has to be amended to include the provision of permissible tax avoidance arrangements. This would help honest taxpayers to arrange their activities in such a way that they would save money and pay less tax to the state.
\end{abstract}

Keywords: Tax avoidance, transaction, operation, scheme, anti-avoidance provisions, impermissible tax avoidance.

\section{Introduction}

"Tax avoidance connotes stratagems which are prima facie lawful, i.e. which are lawful unless expressly proscribed by the Act."1 Many taxpayers seek ways of arranging their affairs so as to escape tax, or reduce or postpone their liability. Persons are free to structure their affairs in order to minimise income tax. In IRC v Duke of Westminster, ${ }^{2}$ Lord Tomlin said that "every man is entitled, if he can, to order his affairs so that the tax attaching under the appropriate Acts is less than it otherwise would be." Furthermore, in CIR $v$ Sunnyside Centre (Pty) $L t d,{ }^{3}$ the court held that "a taxpayer is entitled to order his affairs so as to pay the minimum of tax." In CIR $v$ Conhage (Pty) (Ltd), ${ }^{4}$ the Supreme Court of Appeals (SCA) said that "within the bounds of any anti-avoidance provisions in the relevant legislation, a taxpayer may minimise his tax liability by arranging his affairs in a suitable manner."

However, courts have expressed their disagreement with regard to tax avoidance. In Lord Vestey's Executors and Another $v$ IRC, ${ }^{5}$ Lord Normand said that "tax avoidance is an evil, but it would be the beginning of much greater evil if the courts were to overstretch the language of the statute in order to subject to taxation people of whom they disapproved."

1 R C Williams. Income tax and Capital Gains Tax in South Africa: Law and Practice. 3ed. (2001) 787 - 788.

2 IRC v Duke of Westminster [1936] AC 1 (HL) 19; CSARS v NWK Ltd [200] 2 All SA 347 SCA) para 42; J Cassidy 'The holy grail: the search for the optimal GAAR' (2009) 126 SALJ 740, 744; E Mazansky 'New section 103 is not likely to satisfy taxman' (2006) 240 Tax Breaks Newsletter 1; J van der Walt 'NWK case casting shadows' 2011 Moneyweb's Tax Breaks 7, 8; K Thersby 'The controversial draft new general anti-avoidance rule' 2006 Moneyweb's Tax Breaks 1; R Satumba Analysis of the general anti-avoidance rule in South Africa and a comparison with foreign anti-avoidance provisions (2011) 10 - 11. Available at http://upetd.up.ac.za/thesis/available/etd09102012-162613/unrestricted/dissertation.pdf (accessed on 29 January 2013); CPP Museka A critical analysis of the requirements of section 80A of the New General Anti-Avoidance Rule (2011) 1. Available at http://upetd.up.ac.za/thesis/available/etd-09052012143758/unrestricted/dissertation.pdf (accessed on 29 January 2013).

3 CIR v Sunnyside Centre (Pty) Ltd (1996) 58 SATC 319 (A) 327

4 CIR v Conhage (Pty) Ltd 19994 SA 1149 (SCA) 1155G-H.

5 Lord Vestey's Executors and Another v IRC [1949] 1 All ER 1108 (HL) 1120; Satumba (note 2) 13. 
Persons who practise tax avoidance deprive a state of income that it must use to discharge its responsibility to people. As a result, measures have been taken to eliminate tax avoidance and allow the state to acquire more resources. The present article will critically analyse tax avoidance in the South African Income Tax Act, as amended, by dealing with the general anti-avoidance provisions under section 103 (1), its 1996 Amendment, prevalence of substance over form in common law, sale and leaseback transactions, critical analysis of the current provisions of tax avoidance and comparison between the new and old provisions of tax avoidance.

\section{The general anti-avoidance provisions under section 103 (1)}

Statutory anti-avoidance provisions fall into two categories: specific anti-avoidance provisions which apply to particular transactions, expressly defined by the Act and of a relatively narrow ambit, and general anti-avoidance provisions which do not target a specific type of anti-avoidance stratagem and have a wide sphere of application. ${ }^{6}$

Many specific anti-avoidance provisions are found in the Income Tax Act. ${ }^{7}$ Section 103 (1) dealt with the general anti-avoidance provision and was introduced in 1978, but it was amended in 1996 and 2006. As key judgments have been decided in the interpretation of section 103, its old format and two subsequent amendments will be analysed. All elements of the old section 103 (1) had to be simultaneously present ${ }^{8}$ and each is examined below.

\subsection{There has to be a transaction, operation or scheme entered into or carried out}

"A scheme may consist of several transactions but they must be connected in the sense of being parts of a preconceived plan, whatever the object of such plan may be."9 In Meyerowitz v CIR, the court held that a transaction which did not form part of the scheme when it was entered into can become part of the scheme if it is later 'pressed into the service of the scheme. ${ }^{10}$

"The ordinary natural meaning of avoiding liability for a tax on income is to get rid of the way of, escape or prevent an anticipated liability." ${ }^{11}$ This usually happens when a taxpayer sells his or her property that produces rent. From the wording of section 103 (1), the alienation of property can be a "transaction, operation or scheme." Such a situation does not arise unless other elements are also fulfilled, such as an "objective abnormality" factor and a subjective sole or main purpose of tax avoidance. ${ }^{12}$

In Ovenstone v SIR, ${ }^{13}$ Trollip JA said that "entered into" does not mean "formulated" but has a connotation of implementation that is similar to "carried out." The court held that "it is only when a transaction, operation or scheme is implemented or carried out, and not at the time it was formulated (i.e. conceived, decided or agreed upon) that it becomes a practical reality vis-à-vis the fiscus." ${ }^{14}$ It followed therefore that, even if the purpose or effect of the scheme at the time was not to avoid liability for tax, it might nevertheless have that effect or might become one of the taxpayer's main purposes when he subsequently carried it out, thereby rendering section 103 (1) applicable if the other elements of the section were fulfilled. ${ }^{15}$ To sum up, a transaction, operation or scheme must have been entered into or carried out.

\subsection{The effect of avoiding or postponing or reducing the liability for the payment of any tax imposed by the Act}

A taxpayer may avoid liability for tax if he or she enters into an operation, transaction or scheme which has the effect to avoid, postpone or reduce the liability for payment of any prescribed tax. In Smith $v$ CIR, ${ }^{16}$ the court held that the ordinary meaning of avoiding liability for a tax on income was "to get out of the way of, escape or prevent an anticipated liability." This usually materialises when a taxpayer sells his or her property that produces income.

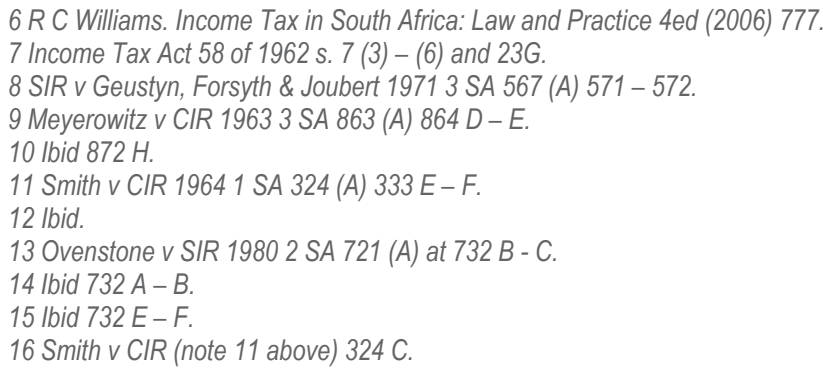


Certain transactions that have the purpose to avoid liability involve the taxpayers who transfer their income, property or advantage to their children. In the Meyerowitz case, the taxpayer entered into a series of transactions which had the effect of transferring to his children income which he would otherwise have received for his labour. The court held that the effect of the transactions was that he avoided liability for tax on that income. ${ }^{17}$ Beyers JA held that where a taxpayer had, by an "artificial manoeuvre", arranged that the income from his labour would accrue to his children and not to him, it was appropriate for the Commissioner to tax the income in the taxpayer's hands, as the person to whom it in reality belonged..$^{18}$ The argument that section 103 (1) applied where the income in question should in reality be the income of the taxpayer was rejected in Smith $v C I R .^{19}$ The court said that the generality of the language of the provision "gives no indication of an intention to limit the inclusion to cases of that nature."20

Once it was proved that a transaction, operation or scheme or change in shareholding or members' interest had the effect of avoiding or postponing or reducing tax, it was presumed that the taxpayer had the requisite purpose of tax avoidance. ${ }^{21}$ However, the taxpayer could avoid liability for tax by rebutting this presumption. This meant that he or she had to prove that he or she did not have the purpose to avoid tax. Currently, the burden of proof that any amount is exempt from, or not liable to, any tax chargeable; subject to any deduction, abatement or set-off; or to be disregarded or excluded in terms of the Eighth Schedule is upon the person claiming such exemption, non-liability, deduction, abatement or set-off, or that such amount must be disregarded or excluded. ${ }^{22}$ Upon the hearing of any appeal from any decision of the Commissioner, the decision is not reversed or altered unless it is shown by the appellant that the decision is wrong. ${ }^{23}$ The taxpayer must discharge the onus of proof in order to succeed in his or her claim.

\subsection{The abnormality test or arm's length test under a transaction, operation or scheme}

The transaction, operation or scheme had to be entered into by means or in a manner which was not normally employed or had created rights or obligations which were not normally created between persons dealing at arm's length. ${ }^{24}$ This test was based on abnormality in two objective aspects: (i) the means and manner which the scheme was entered into or carried out; or (ii) the rights and obligations not normally created between persons dealing at arm's length under such a transaction, operation or scheme. ${ }^{25}$

In Hicklin v SIR, ${ }^{26}$ the court held that "dealing at arm's length" was a useful and often easily determinable premise from which to start the inquiry. It connoted that each party was independent of the other and, in so dealing, would strive to get the uttermost possible advantage out of the transaction for himself or herself. Hence, in an arm's length agreement, the rights and obligations it created were most likely to be regarded as normal then abnormal. The means or manner employed in entering into it or carrying it out were also more likely to be normal than abnormal. ${ }^{27}$ The emphasis should also be placed on surrounding circumstances. Therefore, "what may be normal because of the presence of circumstances surrounding the entering into or carrying out of an agreement in one case, may be abnormal in an agreement of the same nature in another case because of the absence of such circumstances."28 "The last observation of the problem of normality or abnormality of such matter is mainly a factual one."29 This means that the court uses evidence, including expert evidence, adduced by either party in order to make a decision.

In applying the arm's length test for abnormality, a particular problem of interpretation arises where, in the transaction in question, the parties were not strangers, but were associated with one another. ${ }^{30}$ This occurs, for example, where professionals decide to form a company and transfer their assets to the same company. In SIR v Geustyn, Forsyth

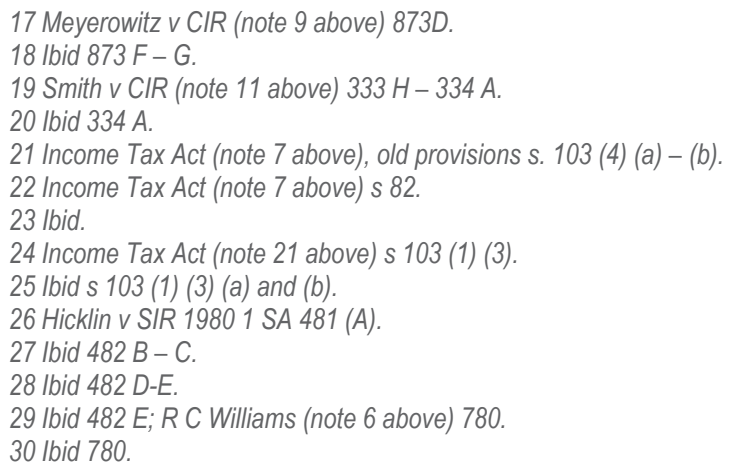


and Joubert, ${ }^{31}$ partners formed and disposed their professional practice to a company that they controlled. The court declined to express an opinion on how the arm's length criterion of abnormality was to be applied where ex hypothesi the taxpayers had not made over their practice to an independent party, but to a company controlled by them. This question was answered by the Appellate Division in CIR v Louw. ${ }^{32}$ It was held that in such a case the court should, "in applying the normality yardstick, take account of the special relationship between the erstwhile partners and the company which they have formed." 33

In the Louw case, professional engineers had transferred their partnership business into an unlimited liability company that they had incorporated. They performed different activities, such as the sale of the partnership assets to the company on credit, interest free; the purchase price to be payable only as the finances of the company permitted; ${ }^{34}$ the lending of large sums to the shareholders, interest free, and without definite terms of payment, 35 the conclusion of service contracts between the company and the shareholders without a set of remuneration and with the taxpayer receiving a lower salary than the income he had earned as a partner for performing the same services. ${ }^{36}$ The court held that these rights and obligations were not abnormal for the nature of the transaction, operation or scheme in question, viz a scheme of incorporation in which partners sold the practice to a company in which they would be shareholders and directors and which they would control. ${ }^{37}$ Taking into considerations all the facts, each partner was trying to extract from the transaction the best possible advantage for himself and the arrangement would be normal for a person dealing with arm's length in this type of transaction. ${ }^{38}$ Therefore there was no abnormality in these transactions or activities.

The same company, a few years after its incorporation, lent to its directors large sums of money out of its profits, interest free and without security. The court held that these loans were not an integral part of the incorporation, but a separate and independent scheme or schemes. ${ }^{39} \mathrm{It}$ had to apply the provisions of section 103 to each loan. Finally, on the facts, the court held that the loans were abnormal, both in respect of the means and manner employed in granting them and as to the rights and obligations created thereby. ${ }^{40}$ The tax avoidance purpose was also established.

The abnormality test has to be satisfied and, when partners decide to form an unlimited company, their special relationships need to be considered. As for the arm's length test, each contracting party seeks to acquire the best advantage he or she can. Furthermore, consideration of the circumstances of each case is necessary. The Commissioner has a challenge to satisfy either one of these requirements.

\subsection{Avoidance, postponement or reduction of the amount of liability had to be the sole or one of the main purposes of the transaction, operation or scheme}

In order to meet all the requirements of section 103 (1), a transaction, operation or scheme must have been entered into solely or mainly for the purposes of avoiding, postponing or reducing liability for a tax imposed by the Act. This is a subjective factor that needs to be present. In CIR v Bobat and Others, ${ }^{41}$ the court held that "a main purpose is obviously one which is dominant over any other." Therefore, where the taxpayer had two purposes of equal significance, one of which is the avoidance of tax, the requirement of main purpose of tax avoidance is not satisfied and section 103 (1) does not apply. ${ }^{42}$

\section{The 1996 amendment to section 103 (1)}

Prior to the 1996 amendment, the Commissioner had to prove all the elements of $\mathrm{s} 103$ (1) in order to succeed in his or her case. According to South African Revenue Services (SARS), a major weakness in s 103 (1) "lay in the 'abnormality'

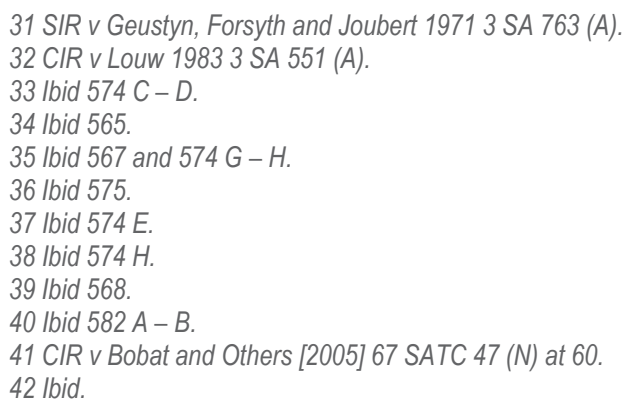


criteria, for it was possible for a taxpayer to argue that it is not 'abnormal' to structure a transaction so as to minimise liability for tax because it is ordinary business to do so." ${ }^{33}$ Furthermore, "even if the transaction was successfully challenged by the Commissioner, interest was not automatically imposed on underpayments of provisional tax." ${ }^{4}$ Section 103 (1) was amended in 1996 in respect of any transaction, operation or scheme which was entered into or carried out on or after 3 July $1996 .{ }^{45}$

The 1996 amendments to section 103 (1) are as follows:

a) In relation to a transaction, operation or scheme "in the context of business", the abnormality tests have been replaced by the criterion of whether or not the transaction was entered into, or carried out, in a manner which would not normally be employed for bona fide business purposes, other than for the obtaining of a tax benefit. ${ }^{46}$ The words of the amendment focus not on the "transaction" itself, but on the "manner" in which it was incurred into or carried out and this probably encompasses, but is not limited to, the rights and obligations involved in the transaction. 47

b) In relation to a transaction, operation or scheme which is not in the interest of business, the Commissioner can exercise his powers under section 103 (1), where it was entered into by means or in a manner which would not normally be employed in the entering into or carrying out of a transaction, operation or scheme of the nature of the transaction, operation or scheme in question. ${ }^{48}$

c) The amended section 103 (1) retains, as an alternative to both (a) and (b) above, one of the old pre- 1996 criteria, namely that the transaction, operation or scheme has created rights or obligations which would not normally be created between persons dealing at arm's length under a transaction, operation or scheme in the nature of the transaction, operation or scheme in question. ${ }^{49}$

d) A new expression -tax benefit- has been introduced into the section and is defined as including, for purpose of section 103 (1) of any avoidance, postponement or reduction of any tax, duty or levy imposed by the Income Tax Act or any other law administered by the Commissioner. ${ }^{50}$

e) It is now specifically provided that where the commissioner has applied the provisions of section 103 (1) in determining a taxpayer's tax liability, he shall not exercise his discretion to waive interest in respect of underpayment of provisional tax in respect of that portion of any tax which is attributable to the application of the section..$^{51}$

The new concept of bona fide business purpose was introduced by this amendment. The transaction, operation or scheme must be entered into with a bona fide business purpose in order to escape the provisions of section 103 (1).

An important instance of this may be where a taxpayer enters into a business transaction in a normal manner for bona fide business purposes, and then later restructures that transaction in the same way (e.g. by amending the applicable contract) in order to obtain a tax benefit that was not available under the transaction in its original form. ${ }^{52}$

There must be a bona fide business purpose in restructuring, otherwise it will fall under the provisions of section 103 (1). Courts use common law to set aside a disguised transaction and give effect to its true meaning when the taxpayer has used it to escape tax provisions.

\section{Common law: Substance prevails over form}

Common law principles advocate that substance prevails over form. In Kilburn v Estate Kilburn, ${ }^{3}$ Wessels ACJ held that "it is a well known principle of our law that courts of law will not be deceived by the form of a transaction: it will rend aside

43 R C Williams op cit (n. 6) 783.

44 Ibid.

45 Income Tax Act 36 of 1996 s. 29; Cassidy (note 2 above) 767; RC Williams "The 1996 amendments to the general anti-avoidance section of the Income Tax Act" (1997) 114 SALJ 765.

46 R C Williams (note 6 above) 783.

47 Income Tax Act (note 7 above) old provisions s. 103 (1) (b) (i) (aa).

48 Ibid s 103 (1) (b) (i) (bb).

49 R C Williams (note 6 above) 783.

50 Income Tax Act (note 7 above) s 103 (7).

51 lbid s 103 (6).

52 R C Williams (note 6 above) 784.

53 Kilburn v Estate Kilburn 1931 AD 501. 
the veil in which the transaction is wrapped and examine its true nature and substance." ${ }^{54}$ Courts do not condone a taxpayer's activity when he or she enters into a simulated transaction in order to escape tax. In Dadoo Ltd and Others $v$ Krugersdorp Municipal Council, ${ }^{55}$ the court stated that a transaction is in fraudem legis when it is designedly disguised so as to escape the provision of the law but falls in truth within these provisions. Thus stated, the rule is merely a branch of a fundamental doctrine that the law regards the substance rather than the form of things. ${ }^{56}$

In order to avoid tax legislation, parties may interpose a tax-exempt institution such as a pension or provident fund. The courts usually ignore the form of such a transaction and give effect to its substance. Two cases are examined below in this regard.

In Erf 3183/1 Ladysmith (Pty) Ltd $v$ CIR, ${ }^{57}$ the taxpayer company wanted to erect a factory in a tax-efficient manner. The taxpayer company made an agreement whereby it leased certain vacant industrial land to a tax-exempt entity (Board of Executor Pension Fund) as a lessee. In terms of the lease, the lessee was entitled, but not obliged, to erect buildings and other improvements on the leased property at its own expenses. The tax-exempt entity sub-leased the land to a subsidiary of the taxpayer. The sublease obliged the sub-lessee (the taxpayer's subsidiary) to erect a factory on the land. All these transactions (lease and sublease) were intended to generate a tax-free benefit to the taxpayer company in erecting a factory on its land. The Commissioner has assessed the taxpayer company and included the value of the factory in its gross income. According to para $(h)$ of the definition of gross income in section 1 of the Income Tax Act, this would only happen if the taxpayer had a right to have the improvements effected. The taxpayer maintained that it did not have such right, since the lessee was merely entitled to effect the improvements. However, the commissioner argued that the documents did not reflect the real intention of the parties and the taxpayer did have such a right.

Hefer JA held that the agreements could not be regarded separately and were plainly interdependent to the extent that none of them would have been concluded without the others. ${ }^{58}$ Therefore, each one had to be considered in the context of all the others to discover their total effect. According to the evidence, parties did not exclude a real likelihood that the agreement did not reflect their true or full intention..$^{59}$ The lease contained a simulation which had the purpose to conceal the real or complete terms of what the parties truly intended, but chose not to express. The court accordingly held that the appellants failed to discharge the onus of proving that the agreement reflected actual intention of the parties and thus failed to show that the right to have improvements effected as envisaged by para ( $h$ ) of the definition of gross income did not accrue to them. ${ }^{60}$ The appeal was dismissed.

The same scenario occurred in Relier (Pty) Ltd $v$ CIR. ${ }^{61}$ In this case, a computer company, Economic Data Processing (Pty) Ltd (EDP), wished to erect a building for its business purposes in the most tax-efficient way possible. The appellant had leased its property to a provident fund which was not subject to income tax. The tenant was not entitled to sublet or make structural alterations or additions without the prior consent of the appellant. In addition, "at the termination of the lease all improvements were to become the property of appellant without compensation." 62 The appellant gave consent to the tenant to sublease and a sublease between the fund and EDP was approved. According to the sublease, EDP (sub-lessee) had an obligation to erect at its own costs an office building of not less than R820 000. Another condition was that the improvements were to become the property of the appellant without any compensation on termination of the sublease. The plan was that the "appellant would get the building as a capital gain without any tax liability because neither the fund nor EDP had any contractual obligation towards it to erect the building."63

54 Ibid 507. J Cassidy "Tainted elements or nugatory directive? The role of the general anti-avoidance provisions ("GAAR") in fiscal interpretation" 2012 Stell LR 319, 326.

55 Dadoo Ltd and Others v Krugersdorp Municipal Council 1920 AD 530.

56 Ibid 547. See also N Joubert "Asset-based financing, contracts of purchase and sale, and simulated transactions" (1992) 109 SALJ 707.

57 Erf 3183/1 Ladysmith (Pty) Ltd v CIR 19963 SA 942 (A). See also R C Williams. "Income Tax: Disguised Transaction: unexpressed Agreement or Tacit Understanding" 114 (1997) SALJ 458 - 561.

58Erf 3183/1 Ladysmith (Pty) Ltd v CIR (note 46 above) 954 C-D.

59 Ibid 956 E.

60 Ibid 956 F.

61 Relier (Pty) Ltd v CIR 60 SATC 1 (1997).

62 lbid 5 .

$63 \mathrm{lbid} 2$. 
The Commissioner contended that the building costs formed part of the appellant's gross income for the particular tax year and issued an additional assessment to tax in this respect according to para (h) of the definition of gross income. The appeal against this decision was dismissed with costs.

In CSARS $\vee N W K, 64$ the court has added a new condition that, for a taxpayer to avoid tax, there must be a "commercial reason" for a transaction and not just an intention to achieve a tax benefit or avoid the application of a law. Lewis JA held that "the test should thus go further and require an examination of the commercial sense of the transaction: of its real substance and purpose." ${ }^{65} \mathrm{He}$ stated that "if the purpose of the transaction is only to achieve an object that allows the evasion of tax, or of a peremptory law, then it will be regarded as simulated." 66 Thus the taxpayer has to demonstrate a commercial reason of his or her transaction in order to avoid tax.

\section{Sale and leaseback transaction}

A taxpayer may enter into a sale and leaseback agreement in order to avoid tax. In CIR v Conhage (Formerly Tycon) (Pty) $L t d,{ }^{67}$ the respondent needed capital and approached Firstcorp Merchant Bank Ltd. The taxpayer wanted to arrange its affairs in a tax-efficient manner. It made an agreement with the bank for the sale and leaseback of its manufacturing plant and equipment. As a result, the taxpayer sought to deduct the rentals paid in terms of the leaseback as expenditure incurred in the production of income under s 11 (a) of the Income Tax Act 58 of 1962. The Commissioner disagreed and the taxpayer successfully appealed to the Special Court for Income Tax Appeals. The Commissioner further appealed to the Supreme Court of Appeals.

The court, per Hefer JA, held "that the evidence showed that parties had not merely been going through the motions of concluding the agreements and had had every intention of putting those agreements into effect." 68 The agreement of sale and leaseback served the dual purpose of providing the taxpayer with capital, while allowing the taxpayer to take advantage of the tax benefits derived from the particular type of transaction. "The advantageous tax deductions were not the only reason for choosing the particular type of transaction but, even if it had, it could not be ignored that, if the taxpayer had not needed any capital, there would have been no transaction at all." 69 The main purpose of the transaction was to procure capital for the taxpayer. The court dismissed the appeal and allowed the deductions of rentals. Under the old provisions of section 103 (1), the Commissioner had extensive powers to deal with tax avoidance.

\section{Powers of the commissioner under section 103 (1)}

If all elements of section 103 (1) are present, the Act empowers the Commissioner to act in two ways, one of them narrow and specific, the other broad and discretionary. ${ }^{70}$ The Commissioner may act to determine liability for tax and the amount thereof, as if the transaction, operation or scheme had not been entered into or carried out. In Newton and Others $v$ COT, ${ }^{71}$ Lord Denning held that the ignoring of transactions -or the annihilation of them- does not itself create liability to tax. In order to make the taxpayers liable, the commissioner must show that moneys have come into the hands of the taxpayers which the commissioner is entitled to treat as income derived by them. ${ }^{72}$

The Commissioner must ascertain that the taxpayer had received a taxable income. In Smith $v C / R,{ }^{73}$ the taxpayer incorporated and controlled companies A, B and C. He expected a dividend in T company in which he held shares. The taxpayer sold the dividend in $\mathrm{T}$ company to $\mathrm{C}$ company. The dividend declared by $\mathrm{T}$ company accrued to $\mathrm{C}$ company, which declared a similar dividend to B company. As a result, the taxpayer had not yet received any dividend. The Commissioner relied on the annihilating power and ignored the transaction of companies $\mathrm{B}$ and $\mathrm{C}$. The Commissioner assessed the taxpayer as if he had received the dividend declared by company $\mathrm{T}$. The court upheld this interpretation

64 CSARS v NWK Ltd [2011] 2 All SA 374 (SCA).

65 Ibid para 55.

66 Ibid para 55.

67 CIR v Conhage (Formerly Tycon) (Pty) Ltd 19944 SA 1149 (SCA).

68 Ibid 1158 D-E. See also A van Zantwijk "Tax avoidance or evasion in 'sale and leasebacks" 2007 Without Prejudice 23, 24.

69 CIR v Conhage (Formerly Tycon) (Pty) Ltd (note 64 above) 1160 F-G; Thersby (note 2 above) 1.

70 R C Williams (note 6 above) 784.

71 Newton and Others v COT [1958] 2 All ER 759 (PC).

72 Ibid 765

73 Smith v CIR (note 11 above), 26 SATC 1. 
and held that had it not been for the offending transaction, the dividend declared by $T$ company "would have come into the taxpayer's hands and he would have been liable to tax on it." "74 Where the offending transaction is ignored or nullified for tax benefits, "he transaction in question remains valid and enforceable between the parties."75

The commissioner may also act in such a manner as, in the circumstances of the case, he deems appropriate for the prevention or diminution of such avoidance, postponement or reduction. This wide-ranging power has to be exercised in accordance with "the general scope of the Act."

Section 103 had major weaknesses hindering the Commissioner to perform his or her duties. "According to the discussion paper, the core perceived weakness of section 103 in its present form is the abnormality test and its interrelationship with the criterion of a 'sole or main purpose of tax avoidance'."77 The other perceived core weakness in section 103 relates to the interplay between the (objective) abnormality requirement and the requirement of a (subjective) sole or main purpose of tax avoidance on the part of the taxpayer. ${ }^{78}$ Because all its elements must be simultaneously present, a taxpayer can with impunity enter into a transaction with the subjective purpose of avoiding tax, provided that the transaction is not objectively abnormal; conversely, a taxpayer can with impunity enter into an abnormal transaction provided that he does not do so for the sole or main purpose of tax avoidance. ${ }^{79}$

The legislature has amended section 103 in order to eliminate its major weaknesses.

\section{Current provisions of tax avoidance}

The new provisions for tax avoidance are found in sections $80 \mathrm{~A}$ to $80 \mathrm{~L}$ of the Income Tax Act. Their purpose is to prohibit impermissible tax avoidance. They contain, inter alia, impermissible tax avoidance arrangements, tax consequences of impermissible tax avoidance, lack of commercial substances, round trip financing, accommodating or tax-indifferent parties and so on. ${ }^{80}$ The new provisions are analysed below.

\subsection{Impermissible tax avoidance arrangements}

An avoidance arrangement is an impermissible avoidance arrangement if its sole or main purpose was to obtain a tax benefit and in the context of business - it was entered into or carried out by means or in a manner which would not normally be employed for bona fide business purposes, other than obtaining a tax benefit; or it lacks commercial substance, in whole or in part. ${ }^{81}$ In a context other than business, an impermissible avoidance arrangement must have been entered into or carried out by means, or in a manner, which would not normally be employed for bona fide purposes, other than obtaining a tax benefit. ${ }^{2}$ In any other context, an impermissible avoidance arrangement must have created rights or obligations that would not normally be created between persons dealing at arm's length; or it would result directly or indirectly in the misuse and abuse of the provisions of the Act. ${ }^{83}$ This last condition is newly created and assists the Commissioner to prevent any tax avoidance. In drawing up the new anti-avoidance provision (section 80A), it would seem the legal draftsman desired a provision that could be used by the Commissioner to prevent tax-saving arrangements from being successful. ${ }^{84}$ This is a major weapon for the Commissioner to deal with the tax avoidance scheme.

74 Ibid 335.

75 R C Williams (note 6 above) 785.

76 Ibid 786

77 Ibid 794

78 Ibid 794

79 Ibid 794.

80 Income Tax Act (note 7 above) s 80A - 80L; Cassidy (note 2 above) 745; L van Schalkwyk \& B Geldenhuys "The nature of the purpose requirement of an impermissible tax avoidance arrangement" (2010) 35 Journal for Juridical Science 71, 78.

81 Income Tax Act (note 7 above) s $80 \mathrm{~A}$ (a).

82 Ibid s $80 A$ (b).

$83 \mathrm{lbid} s 80 \mathrm{~A}$ (c).

84 L Mitchell "No entry Route to Ladysmith closed" (2007) 21 Tax Planning 123 (123 - 125). 


\subsection{Tax consequences of impermissible tax avoidance}

The Commissioner may determine the tax consequences under this Act of any impermissible avoidance arrangement for any party by:

a) disregarding, combining, or re-characterising any steps in or parts of the impermissible avoidance arrangement; $; 5$

b) disregarding any accommodating or tax-indifferent party or treating any accommodating or tax-indifferent party and any other party as one and the same person; 86

c) deeming persons who are connected persons in relation to each other to be one and the same person for purposes of determining the tax treatment of any amount; $; 8$

d) reallocating any gross income, receipt or accrual of a capital nature, expenditure or rebate amongst the parties; 88

e) re-characterising any gross income, receipt or accrual of a capital nature or expenditure; 89 or

f) treating the impermissible avoidance arrangement as if it had not been entered into or carried out, or in such other manner as in the circumstances of the case the Commissioner deems appropriate for the prevention or diminution of the relevant tax benefit..$^{90}$

"As detailed above, section 80B provides the Commissioner with six possible remedies to combat an impermissible avoidance arrangement." "The last remedy, as set out in section 80B (1) (f), was the sole remedy available to the Commissioner when applying the provision of section 103 (1) to a tax avoidance scheme." 92 The Commissioner is empowered with more remedies to determine the tax consequences of any party to an impermissible avoidance arrangement.

Subject to the legally imposed time limit, ${ }^{93}$ the Commissioner must make compensating adjustments that he or she is satisfied are necessary and appropriate to ensure the consistent treatment of all parties to the impermissible avoidance arrangement. ${ }^{94}$ The Commissioner can make an additional assessment of a taxpayer if he or she is satisfied that there is an amount which has not been assessed to tax, provided that three years after the date of assessment have not expired. ${ }^{95}$ However, in spite of the expiration of three years, the Commissioner may still make an additional assessment if he or she is satisfied that the amount chargeable to tax was not assessed due to fraud or misrepresentation or nondisclosure of material fact; or the Commissioner or taxpayer agree otherwise (prior to the expiry of the three-years period)..$^{96}$ This provision eliminates any misconduct of the taxpayer in the assessment of tax payable. The Commissioner shall not reduce any assessment after the expiration of three years from the date of such assessment, or if the amount was assessed in terms of an assessment accepted by the taxpayer and which was made in accordance with the practice generally prevailing at the date of that assessment. ${ }^{97}$ The Commissioner may not extend the period of objections "where more than three years have lapsed from the date of the assessment." ${ }^{.98}$ Likewise, he or she may not extend the time of objection for a period exceeding 30 days, unless exceptional circumstances exist which gave rise to the delay in lodging the objection. ${ }^{99}$ The Commissioner has discretion to extend the prescribed period in order to prevent or eliminate impermissible tax avoidance.

85 Income Tax Act (note 7 above) s $80 B$ (1) (a).

$86 \mathrm{lbid} s 80 \mathrm{~B}(1)$ (b).

$87 \mathrm{lbid} s 80 \mathrm{~B}(1)$ (c).

$88 \mathrm{lbid} s 80 \mathrm{~B}(1)(\mathrm{d})$.

89 lbid s $80 B$ (1) (e).

90 Ibid s 80B (1) (f).

91 L Mitchell "A la Carte Section 80B" (2008) 22 Tax Planning 15 at 16.

92 Ibid 16.

93 Income Tax Act (note 7 above) s 79, 79A (2) (a) and 81 (2) (b) (three-years period).

94 Ibid s 80B (2).

95 Ibid s 79 (1) (1).

96 Ibid s 79 (1) (1) (aa) and (bb).

97 Ibid s $79 A$ (2).

$98 \mathrm{lbid} s 81$ (2) (b).

$99 \mathrm{lbid} s 81$ (2) (a). 


\subsection{Notice}

The Commissioner must, prior to determining any liability of a party for tax under section $80 \mathrm{~B}$, give the party notice that he or she believes that the provisions of Part II may apply in respect of an arrangement and must set out his or her reasons in the notice. ${ }^{100} \mathrm{~A}$ party who received such a notice may, within 60 days after the date of that notice, or such longer period as the Commissioner may allow, submit reasons to the Commissioner why the provisions of Part II should not be applied. ${ }^{101}$ The Commissioner must, within 180 days of receipt of the reasons, or the expiry of 60 days, request additional information to determine whether or not Part II applies in respect of an arrangement; give notice to the party that the notice in terms of section $80 \mathrm{~J}$ (1) has been withdrawn, or determine the liability of that party for tax in terms of Part II. 102

If, at any stage after giving notice to the party in terms of section $80 \mathrm{~J}(1)$, additional information comes to the knowledge of the Commissioner, he or she may revise or modify his or her reasons for applying this Part II or, if the notice has been withdrawn, give notice in terms of section $80 \mathrm{~J}(1){ }^{103}$

\subsection{Lack of commercial substance}

For the purpose of this Part, an avoidance arrangement lacks commercial substance if it would result in a significant tax benefit for a party, but does not have a significant effect upon either the business risks or net cash flow of that party, apart from any effect attributable to the tax benefit that would be obtained, but for the provision of this Part. ${ }^{104}$ Characteristics of an avoidance arrangement that are indicative of lack of commercial substance include, but are not limited to, the legal substance or effect of the avoidance arrangement as a whole is inconsistent with, or differs significantly from, the legal form of its individual steps. ${ }^{105}$ They also include the inclusion or presence of round trip financing, as described in section $80 \mathrm{D}$, or an accommodating or tax indifferent party, as described in section $80 \mathrm{G}$, or elements that have the effect of offsetting or cancelling each other. ${ }^{106}$

For the purpose of applying lack of commercial substance, or determining whether or not a tax benefit exists, the Commissioner may treat parties who are connected persons in relation to each other as one and the same person; or disregard any accommodating or tax indifferent party, or treat any accommodating or tax-indifferent party and any other party as one and the same person. ${ }^{107}$

\subsection{Round trip financing}

Round trip financing includes any avoidance arrangement in which funds are transferred between or among the parties (round tripped amounts); and the transfer of such funds would result, directly or indirectly, in a tax benefit but for the provisions of this Part; and significantly reduce, offset or eliminate any business risk incurred by any party in connection with the avoidance arrangement. ${ }^{108}$ This provision may prevent parents from transferring their income to their children and plays a significant role in eliminating impermissible tax avoidance. The section also applies to any round tripped amounts without regard to whether or not they can be traced to funds transferred to, or received by, any party in connection with the avoidance arrangement; the timing or sequence in which round tripped amounts are transferred or received; or the means by, or manner in which, round tripped amounts are transferred or received. ${ }^{109}$

\subsection{Accommodating or tax-indifferent parties}

\footnotetext{
100 lbid s 80J (1).

$101 \mathrm{lbid} s$ 80J (2).

102 lbid s $80 \mathrm{~J}(3)$.

$103 \mathrm{lbid} s$ 80J (4).

104 Ibid s 80C (1).

105 Ibid s 80C (2) (a).

106 Ibid s 80C (2) (b).

$107 \mathrm{lbid} s$ 80F (a) and (b).

$108 \mathrm{lbid} s 800$ (1).

109 lbid s 80D (2).
} 
A party to an avoidance arrangement is an accommodating or tax-indifferent party if any amount derived by the party in connection with the avoidance arrangement is either not subject to normal tax, or significantly offset either by any expenditure or loss incurred by the party in connection with that avoidance arrangement or any assessed loss of that party. ${ }^{110} \mathrm{~A}$ person may be an accommodating or tax-indifferent party whether or not that person is a connected person in relation to any party. ${ }^{111}$ The Act states the circumstances in which the provisions of this section do not apply. The party may not be subjected to double taxation. ${ }^{112}$

\subsection{Presumption of purpose}

An avoidance arrangement is presumed to have been entered into or carried out for the sole or main purpose of obtaining a tax benefit, unless and until the party obtaining a tax benefit proves that, reasonably considered in the light of the relevant facts and circumstances, obtaining a tax benefit was not the sole or main purpose of the avoidance arrangement. ${ }^{113}$ The onus is placed on the taxpayer to prove that the obtention of a tax benefit was not the sole or main purpose of the avoidance arrangement. If he or she fails to discharge the onus, the Commissioner will succeed in his or her operation to prevent impermissible tax avoidance. The purpose of a step in, or part of, any avoidance arrangement may be different from a purpose attributable to the avoidance arrangement as a whole..$^{114}$

\subsection{Interest}

Where the Commissioner has applied Part II in determining a party's liability for tax, he or she may not exercise his or her discretion in terms of section 89quat (3) or (3A) to direct that the interest is not payable in respect of that portion of any tax which is attributable to the application of Part II. ${ }^{115}$ This provision disempowers the Commissioner of his or her right to disallow payment of interest by the taxpayer in respect of any year of assessment where there has been impermissible tax avoidance. As a result, the taxpayer must pay the interest where he or she commits an impermissible tax avoidance.

\section{Comparison between new and old provisions of tax avoidance}

The new provisions of impermissible tax avoidance have retained some features of the previous regulations. The Amendment retains the sole or main purpose of obtaining a tax benefit, the abnormality test, and arm's length test. ${ }^{116}$ The Commissioner has the previous remedies to deal with a tax avoidance scheme, operation or transaction. ${ }^{117} \mathrm{He}$ or she can treat the impermissible avoidance arrangement as if it had not been entered into or carried out. The Commissioner may also treat tax avoidance in such other manner in the circumstances of the case as he or she deems appropriate for the prevention or diminution of the relevant tax benefit. 118

The Amendment has introduced new provisions to assist the Commissioner to combat or eliminate impermissible tax avoidance. It has extended the concept of the impermissible tax avoidance arrangement. An avoidance arrangement is an impermissible avoidance arrangement if its sole or main purpose was to obtain a tax benefit and in any context it has created rights or obligations that would not normally be created between persons dealing at arm's length; or it would result directly or indirectly in the misuse or abuse of the provisions of this Act (including the provisions of this Part). ${ }^{119}$ This provision encompasses every section of the Income Tax Act. The Commissioner is empowered to follow anyone whose activity amounts to an impermissible tax avoidance arrangement by using the entire Act and other legislation. Almost every activity may amount to an impermissible tax avoidance arrangement, with the result that the Commissioner will intervene to prevent it. The major weakness of the new provisions is that they do not mention or provide what constitutes a permissible tax avoidance, so that the taxpayer can arrange his or her affairs accordingly. Such a weakness

\footnotetext{
110 lbid s $80 E$ (1) (a).

$111 \mathrm{lbid} s 80 \mathrm{E}$ (2).

112 Ibid s 80E (4).

113 Ibid s $80 G$ (1).

114 Ibid s $80 G$ (2).

$115 \mathrm{lbid} s$ 80K.

$116 \mathrm{lbid} s$ 80A (a), (b) and (c).

117 Ibid s 80B (1) (f).

118 lbid.

$119 \mathrm{lbid} s 80 \mathrm{~A}$ (c).
} 
is a significant drawback in the business activities of the taxpayer. The provisions tend to tell the persons how to organise their business. In the eyes of the taxpayers, the impermissible tax avoidance arrangement works against them.

The Amendment has also increased the remedies available to the Commissioner to nullify an impermissible tax avoidance arrangement. He or she can disregard any steps in, or parts of, the impermissible tax avoidance arrangement; disregard any accommodating or tax-indifferent party; and reallocate or re-characterise any gross income. ${ }^{120}$ These new remedies assist the Commissioner to perform his or her duty to eliminate any impermissible tax arrangement. The Commissioner is in a better position than before to defeat impermissible tax avoidance.

\section{Conclusion}

Everybody can organise his or her business in order to reduce, postpone or avoid tax, as long as he or she operates within the boundaries of the legislation. Tax avoidance is evil, as it deprives the state of the resources that it can use to meet its expenditure and responsibilities. Previously, the Commissioner had to prove certain elements in order to prevent tax avoidance. There had to be a transaction, operation or scheme that had been entered into with the sole or main purpose of avoiding, postponing or reducing the liability to pay tax. The arm's length test and abnormality test needed to be satisfied for the Commissioner to succeed in preventing tax avoidance. Tax avoidance had to be the whole or main purpose of a transaction, operation or scheme.

These provisions were very weak and the Commissioner did not succeed in his or her activities. The new Amendment has introduced new remedies for the Commissioner to use to prevent impermissible tax avoidance arrangements. The Commissioner can use the Income Tax Act and other legislation to avoid impermissible tax avoidance arrangements. The Amendment protects the Commissioner to the detriment of the taxpayers. There is a provision for impermissible tax avoidance arrangement but the legislature did not provide for permissible tax avoidance arrangements. The new provisions for tax avoidance seem to structure how taxpayers should arrange their businesses. It is recommended that the law has to be amended to include the provision of permissible tax avoidance arrangements. This would help honest taxpayers to arrange their activities in such a way that they would save money and pay less tax to the state.

\section{References}

Williams, R C. Income tax and Capital Gains Tax in South Africa: Law and Practice. 3rd ed. Durban: LexisNexis Butterworths (2001) Williams, R C. Income Tax in South Africa: Law and Practice. 4ed. Durban: LexisNexis Butterworths (2006)

Cassidy, J "Tainted elements or nugatory directive? The role of the general anti-avoidance provisions ('GAAR') in fiscal interpretation" 2012 Stell LR 319

Cassidy, J "The holy grail: the search for the optimal GAAR" (2009) 126 SALJ 740

Joubert, N "Asset-based financing, contracts of purchase and sale, and simulated transactions" (1992) 109 SALJ 707

Mazansky, E "New section 103 is not likely to satisfy taxman" (2006) 240 Tax Breaks Newsletter 1

Mitchell, L "A la Carte Section 80B" (2008) 22 Tax Planning 15

Mitchell, L "No entry Route to Ladysmith closed" (2007) 21 Tax Planning 123

Thersby, K "The controversial draft new general anti-avoidance rule" 2006 Moneyweb's Tax Breaks 1

Van der Walt, J "NWK case casting shadows" 2011 Moneyweb's Tax Breaks 7

Van Schalkwyk, L \& B Geldenhuys "The nature of the purpose requirement of an impermissible tax avoidance arrangement" 2010 Journal for Juridical Science 72

Van Zantwijk, A "Tax avoidance or evasion in 'sale and leasebacks"' 2007 Without Prejudice 23

Williams, RC "Income Tax: Disguised Transaction: unexpressed Agreement or Tacit Understanding" 114 (1997) SALJ 458

Income Tax Act 58 of 1962

CIR v Bobat and Others [2005] 67 SATC 47 (N)

CIR v Conhage (Formerly Tycon) (Pty) Ltd 19944 SA 1149 (SCA)

CIR v Conhage (Pty) Ltd 19994 SA 1149 (SCA)

CIR v King 19472 SA 196 (A)

CIR v Louw 19833 SA 551 (A)

CIR v Sunnyside Centre (Pty) Ltd (1996) 58 SATC 319 (A)

CSARS v NWK Ltd [200] 2 All SA 347 SCA)

Dadoo Ltd and Others v Krugersdorp Municipal Council 1920 AD 530

Erf 3183/1 Ladysmith (Pty) Ltd v CIR 19963 SA 942 (A) 
Hicklin v SIR 19801 SA 481 (A)

IRC v Duke of Westminster [1936] AC 1

Kilburn v Estate Kilburn 1931 AD 501

Lord Vestey's Executors and Another v IRC [1949] 1 All ER 1108 (HL)

Meyerowitz v CIR 19633 SA 863 (A)

Newton and Others v COT [1958] 2 All ER 759 (PC)

Ovenstone v SIR 19802 SA 721 (A)

Relier (Pty) Ltd v CIR 60 SATC 1 (1997)

SIR v Geustyn, Forsyth and Joubert 19713 SA 763 (A)

Smith v CIR 19641 SA 324 (A), 26 SATC 1

Museka, CPP A critical analysis of the requirements of section 80A of the New General Anti-Avoidance Rule (2011) 1. Available at http://upetd.up.ac.za/thesis/available/etd-09052012-143758/unrestricted/dissertation.pdf (accessed on 29 January 2013)

Satumba, R Analysis of the general anti-avoidance rule in South Africa and a comparison with foreign anti-avoidance provisions (2011) 10 - 11. Available at http://upetd.up.ac.za/thesis/available/etd-09102012-162613/unrestricted/dissertation.pdf (accessed on 29 January 2013) 
